Quebecor - Position Product Application Focus graphic and blurb here. Pick up from Vol. 11, No. 3, p. 392

\title{
Paper-Based Archiving of Mammalian and Plant Samples for RNA Analysis
}

\author{
P. Natarajan, T. Trinh, L. Mertz, M. Goldsborough, and D.K. Fox \\ Life Technologies, Rockville, MD, USA
}

BioTechniques 29:1328-1333 (December 2000)

\begin{abstract}
The ability to archive biological samples for subsequent nucleic acid analysis is essential for tissue specimens and forensic samples. $F T A^{\circledR}$ Card is a chemically treated filter paper designed for the collection and room temperature storage of biological samples for subsequent DNA analysis. Its usefulness for the preservation of biological samples for subsequent RNA analysis was tested. Here, we demonstrate that RNA in biological samples stored on FTA Cards is stable and can be used successfully for RT-PCR and northern blot analysis. $R N A$ stability depends on the storage temperature and the type of biological specimen. RNA in mammalian cells stored on FTA Cards is stable for over one year at temperatures at or below $-20^{\circ} \mathrm{C}$ and for two to three months in samples stored at room temperature. For plant leaf, longer storage times (> 5 days) require temperatures at or below $70^{\circ} \mathrm{C}$ following sample application. FTA Cards may constitute a method not only for convenient collection and storage of biological samples but also for rapid RT-PCR analysis of tissue and cell samples.
\end{abstract}

\section{INTRODUCTION}

The FTA ${ }^{\circledR}$ Card is a chemically treated filter paper designed for the collection and room temperature storage of biological samples for subsequent DNA analysis $(1,2,5)$. It is suitable for storage of blood samples as well as a variety of cells and tissues for PCR analysis and other genomic DNA applications (10). It is useful for recovery of plasmid DNA for PCR and for transformation from archived bacterial cultures and colonies $(6,8)$, as well as for storage and recovery of $E$. coli M13 phage DNA for DNA sequencing applications (data not shown). In addition to archiving samples for DNA analysis, it would be beneficial to researchers if biological samples could be similarly archived for RNA analysis. This report de- scribes the utility of the FTA Card in the collection and storage of samples of plant and animal origin.

\section{MATERIALS AND METHODS}

All reagents and media were from Life Technologies (Rockville, MD, USA) unless otherwise stated.

\section{Cell Culture}

HeLa cells were grown in suspension in S-MEM supplemented with $10 \%$ heat-inactivated horse serum and $4 \mathrm{mM}$ glutamine. BHK-21 cells were grown in monolayer as described previously (4), and suspensions were prepared by trypsinization $(0.05 \%$ trypsin solution) followed by washing and resuspension in Dulbecco's PBS (containing $\mathrm{Ca}^{2+}$ and $\mathrm{Mg}^{2+}$ ) at the appropriate cell density. Resuspended cells were spotted on FTA Cards using an adjustable pipettor, and similar control samples were vialed and quick-frozen in a dry-ice ethanol bath and stored at $-70^{\circ} \mathrm{C}$.

\section{Preparation and Storage of Samples}

Blood $(20 \mu \mathrm{L})$ and $5 \mu \mathrm{L}$ HeLa cell suspension $\left(1 \times 10^{7}\right.$ cells $/ \mathrm{mL}$ ) were spotted directly on FTA Cards, allowed to airdry for up to $2 \mathrm{~h}$, and stored at room temperature, $4^{\circ} \mathrm{C},-20^{\circ} \mathrm{C}$, or $-70^{\circ} \mathrm{C}$ in sealed foil packages containing desiccant. Gene Guard Swabs containing buccal cells were applied onto FTA Cards, allowed to air dry for up to $2 \mathrm{~h}$, and stored at room temperature in sealed foil packages with desiccant. Potato plant leaf samples were pressed onto FTA Cards using a nitrogen-driven press (17.5 psi) and treated as described above. 


\section{PCR of Genomic DNA}

Using a HARRIS MICRO-PUNCH ${ }^{\mathrm{TM}}$, 2-mm punches were removed from blood samples stored on FTA. The punches were each placed in $1.5-\mathrm{mL}$ microcentrifuge tubes and processed by incubating $3 \times 5$ min with FTA Purification Reagent $(200 \mu \mathrm{L})$ at room temperature followed by $2 \times 5 \mathrm{~min}$ incubations with $200 \mu \mathrm{L}$ TE $(10 \mathrm{~mm}$ Tris- $\mathrm{HCl}, \mathrm{pH} 8.0$, and $0.1 \mathrm{mM}$ EDTA) at room temperature. Each punch was processed individually and then transferred to a thin-walled amplification tube. Amplification was performed by using PlATINUM $^{\circledR}$ Taq High Fidelity DNA polymerase $(1 \mathrm{U})$, in $1 \times$ Platinum Taq High Fidelity PCR Buffer, $200 \mu \mathrm{M}$ dNTPs, $200 \mathrm{nM}$ primers, and $2 \mathrm{mM} \mathrm{MgSO}_{4}$.

\section{RT-PCR}

Using a HARRIS MICRO-PUNCH, 2-mm punches were transferred to $1.5-\mathrm{mL}$ low-binding RNase-free DNase-free tubes (Marsh Biomedical, Rochester, NY, USA) containing $400 \mu \mathrm{L}$ RNA processing buffer $(10 \mathrm{mM}$ Tris- $\mathrm{HCl}, \mathrm{pH} 8.0,0.1$ mM EDTA, 400-800 U/mL RNASEOUT ${ }^{\mathrm{TM}}$, and $2 \mathrm{mM}$ DTT) and incubated on ice for 15 min with vortex mixing every 5 min. In some experiments, the processing buffer also contained $250 \mu \mathrm{g} / \mathrm{mL}$ glycogen to facilitate subsequent precipitation of the RNA. Unlike genomic DNA, RNA elutes from the filter punches during this incubation. RT-PCR was done either directly using the processing buffer eluate as substrate or using RNA precipitated from the eluate. The RNA was precipi- tated by addition of salt ( 0.1 volumes of $3 \mathrm{M}$ sodium acetate or 0.5 volumes of $7.5 \mathrm{M}$ ammonium acetate) and 0.5 volumes of ice-cold $100 \%$ isopropanol. The samples were placed at $20^{\circ} \mathrm{C}$ overnight, spun down at $12000 \times g$ in the microcentrifuge, washed with $75 \%$ ethanol (ice-cold), and allowed to air-dry. RNA pellets were resuspended in 50 or $100 \mu \mathrm{L}$ sterile TE. Synthesis of first-strand cDNA was performed using SUPERSCRIPT $^{\text {TM }}$ II RNase H- reverse transcriptase (Life Technologies) according to the manufacturer's protocol, except the reaction was performed at $50^{\circ} \mathrm{C}$ in a final volume of $50 \mu \mathrm{L}$ containing $40 \mathrm{U}$ RMSEOUT. The amount of RNA used in the first-strand cDNA synthesis is indicated in the figure legends. Amplification reactions $(50 \mu \mathrm{L})$ contained less than or equal to $10 \mu \mathrm{L}$ of the cDNA reaction and the following: $1 \times$ Amplification Buffer, $1.8 \mathrm{mM} \mathrm{MgSO}, 200 \mathrm{nM}$ primers, $200 \mu \mathrm{M}$ each dNTP, and 2.5 U PLATINUM Taq DNA polymerase. Thermal cycling parameters and primer sequences for each target are provided in the figure legends. For templates larger than 4 kb, 1-2 U Platinum Taq DNA Polymerase High Fidelity was used. Amplification products were analyzed by $1.2 \%$ TBE or $0.8 \%$ TAE agarose gel electrophoresis (9). Primer sequences are given in Table 1.

\section{Isolation of Poly $(A)+$ RNA Directly from Cells on FTA}

BHK-21 cell suspension $(20-50 \mu \mathrm{L})\left(4.25 \times 10^{7} / \mathrm{mL}\right)$ was spotted directly onto FTA Cards and stored at $-70^{\circ} \mathrm{C}$ as described above or placed in tube, frozen in dry ice ethanol and, stored at $-70^{\circ} \mathrm{C}$. For RNA isolation, the entire spot was cut

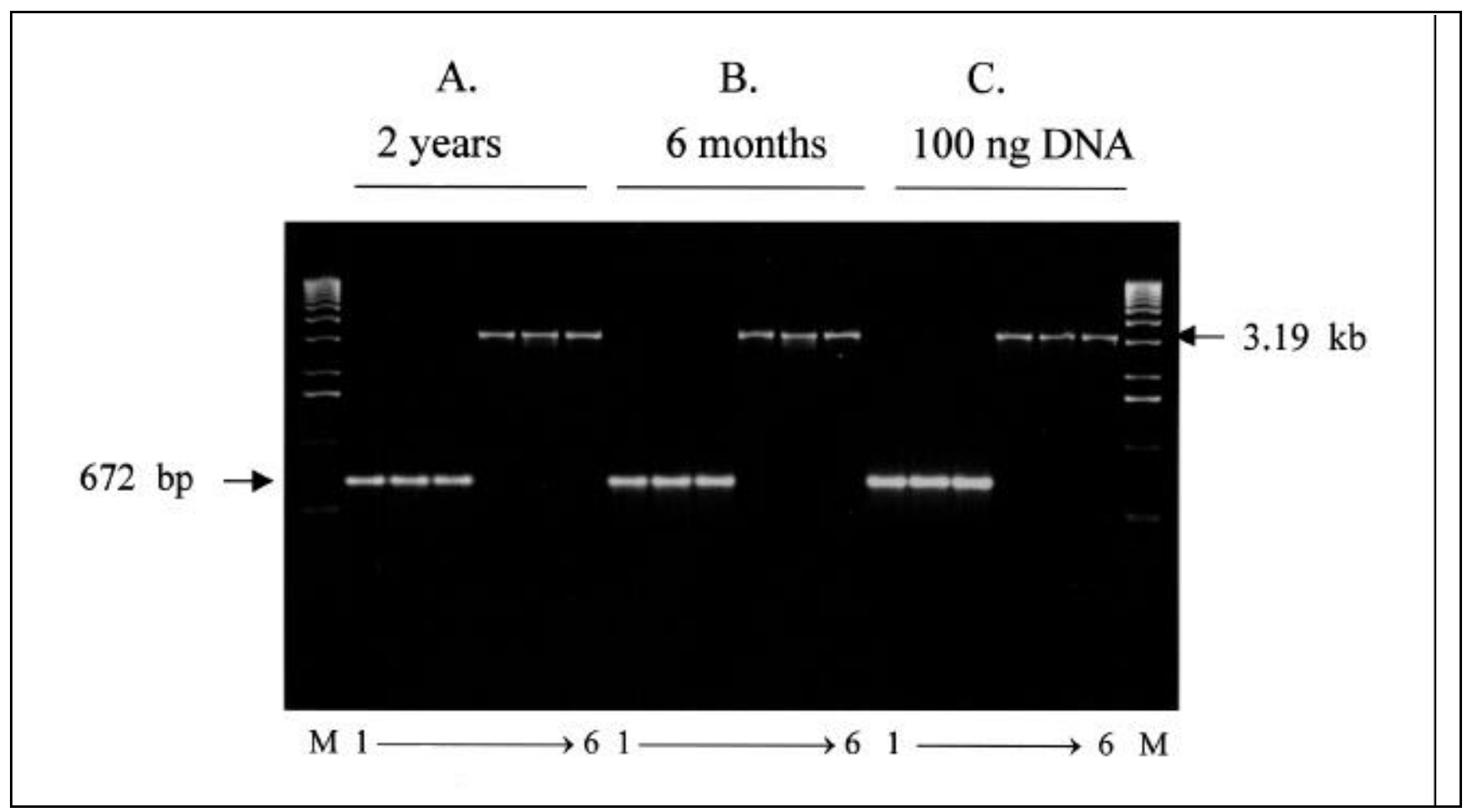

Figure 1. Amplification of genomic DNA from human blood samples. Punches were taken from the blood samples stored for two years (A) and for six months (B), and amplification of 672-bp (lanes 1-3) and 3.19-kb (lanes 4-6) $\beta$-actin targets was performed as described in Materials and Methods. The primer sequences used are as follows: 672-bp forward and reverse primers: 5'-CTGCAGTCCCAGGCTATTCAGG-3' and 5'-AGACTTGGACCATGACGGTGAT-3', respectively; 3.19 -kb forward and reverse primers: 5'-CTGCTGAAAGAGATGCGGTGG-5' and 5'-TCTTCCCAAAATGCCCTGAGT-3', respectively. Each lane represents a different punch of the archived biological sample. (C) K562 genomic DNA (100 ng) as amplification substrate. Marker is the 1-kb DNA ladder. Thermal cycling conditions were $94^{\circ} \mathrm{C}$ for $30 \mathrm{~s}$, followed by 35 cycles of $95^{\circ} \mathrm{C}$ for $15 \mathrm{~s}, 64^{\circ} \mathrm{C}$ for $30 \mathrm{~s}$, and $72^{\circ} \mathrm{C}$ for 4.5 min. Amplification products were analyzed on a $1.0 \%$ TAE agarose gel. 
Table 1. Primer Sequences Used

\begin{tabular}{|llc|}
\hline Target (Human) & Primer Sequences & Product Size \\
\hline$\beta$-globin & Sense: 5'-CTGCAGTCCCAGGCTATTCAGG-3' & $1.3 \mathrm{~kb}$ \\
$\beta$-globin & Antisense: 5'-AGACTTGGACCATGACGGTGAT-3' & $3.19 \mathrm{~kb}$ \\
& Sense: 5'-CTGCTGAAAGAGATGCGGTGG-3' & \\
Cysteine protease (plant) & Antisense: 5'-TCTTCCCAAAATGCCCTGAGT-3' & $1.05 \mathrm{~kb}$ \\
& Sense: 5'-TCGCCGATCTGACTAATGAGGAG-3' & \\
Replication protein A & Antisense: 5'-ATGCGCTTCATTGCCTTCACTCC-3' & $1.08 \mathrm{~kb}$ \\
$\beta$-actin & Sense: 5'-CAAGATGTGGAACAGTGGATTC-3' & \\
& Antisense: 5'-CATCTATCTTGATGTTGTAACAAGC-3' & $0.626 \mathrm{~kb}$ \\
Clathrin-like protein & Sense: 5'-CCTCGCCTTTGCCGATCC-3' & \\
& Antisense: 5'-GGATCTTCATGAGGTAGTCAGTC-3' & $5.76 \mathrm{~kb}$ \\
& Sense: 5'-CCCAGTGACAGGAGGAGACCATA-3' & \\
\end{tabular}

into small pieces using a razor blade and added to $750 \mu \mathrm{L}$ sterile water followed by incubation at room temperature for 7 min with frequent vortex mixing. To remove the filter pieces, the eluate was passed through a shredder microcentrifuge tube, and the poly $(\mathrm{A})^{+}$RNA was isolated by selection with oligonucleotide(dT). Typical yields from these samples were $300 \mathrm{ng}$ mRNA/ $2 \times 10^{6}$ cells. Total RNA from the same number of BHK-21 cells was isolated using TRIzOL ${ }^{\circledR}$ Reagent according to the manufacturer's directions, and poly $(\mathrm{A})^{+}$RNA was isolated from these samples by selection with oligo(dT) as well.

\section{Northern Blot Analysis of RNA}

Total RNA and poly(A)+ RNA were subjected to electrophoresis in a 1.2\%, $1 \times$ MOPS, $30 \%$ formaldehyde agarose gel as described previously (9), followed by transfer to a nylon membrane. The blot was baked at $80^{\circ} \mathrm{C}$ for $1 \mathrm{~h}$ followed by prehybridization as previously described (9). ${ }^{32} \mathrm{P}$-labeled $\beta$-actin probe was prepared using the RadPrime DNA Labeling System and was adjusted to a final concentration of $5 \times$ $10^{6} \mathrm{cpm} / \mathrm{mL}$ hybridization buffer. Hybridization was performed as described previously (9) for $16 \mathrm{~h}$ at $42^{\circ} \mathrm{C}$. The blot was washed $3 \times 5$ min with $2 \times \mathrm{SSC}(9)$ containing $0.1 \%$ SDS at room temperature and $2 \times 30$ min with $0.25 \times \mathrm{SSC}$ containing $0.1 \% \mathrm{SDS}$ at $65^{\circ} \mathrm{C}$. The blot was then placed in plastic wrap and exposed to X-ray film.

\section{RESULTS}

Figure 1 demonstrates amplification of 0.672- and 3.19-kb genomic DNA $\beta$-globin targets from a human blood sample that was spotted onto an FTA Card and stored at room tem perature for up to two years. These data are in agreement with similar results demonstrating excellent maintenance of DNA integrity by this archival method $(3,10)$. To investigate the integrity of RNA in mammalian cell samples stored on FTA Cards, we isolated total and poly $(\mathrm{A})^{+}$RNA from the same number of BHK-21 cells that were either vialed or spotted on FTA Cards and stored at $-70^{\circ} \mathrm{C}$. We then performed northern analysis on the poly $(\mathrm{A})^{+}$RNA isolates (Figure 2) using a ${ }^{32} \mathrm{P}$ labeled $\beta$-actin probe. The quality of the $2.2-\mathrm{kb}$ signal from the archived samples is directly comparable to that of RNA isolated from vialed BHK-21 cells by traditional means. The signal intensity the RNA isolated from FTA Cards is lower than that from the RNA from the vialed cells. This is most probably due to differences in the yield of RNA. Based on these results, it appears that the integrity of poly $(\mathrm{A})^{+} \mathrm{RNA}$ from mammalian cell samples spotted onto FTA Cards is

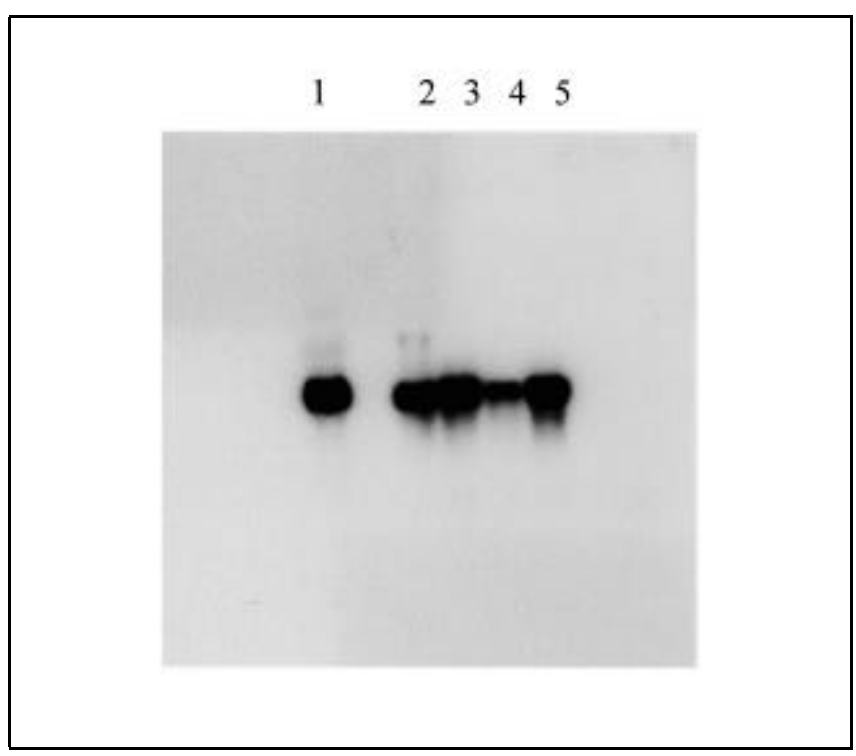

Figure 2. Northern blot of RNA isolated from the FTA Card. Total RNA (lane 1) was isolated from BHK-21 cells using TRIzol Reagent. Poly(A) ${ }^{+}$ RNA was isolated from the total RNA (lanes 2 and 3) or directly from BHK21 cells applied to the FTA Card and stored for approximately one month (lanes 4 and 5) as described in Materials and Methods. The RNA was subjected to electrophoresis on a denaturing agarose gel, and a northern blot was done using a ${ }^{32} \mathrm{P}$-labeled probe specific to $\beta$-actin mRNA. The number of cells used was $2.5 \times 10^{6}$ (lanes 2 and 4) and $4 \times 10^{6}$ (lanes 1, 3, and 5). 
maintained. However, we have found that, after application of mammalian cells onto FTA paper, the samples must be placed at temperatures less than or equal to $-20^{\circ} \mathrm{C}$ for long-term storage greater than two to three months. RNA integrity in sam ples stored at room temperature or $4^{\circ} \mathrm{C}$ for extended periods was suboptimal compared to samples stored at temperatures less than or equal to $-20^{\circ} \mathrm{C}$ (data not shown). This loss of integrity was measured as a decreased RT-PCR signal relative to control RNA. Genomic DNA contained in FTA-archived samples stored at room temperature for up to 7.5 years has been shown to be intact (3), which is quite different from our observations with RNA.

We further investigated RNA stability on FTA Cards stored at temperatures less than or equal to $-20^{\circ} \mathrm{C}$ by performing RTPCR analysis on different mRNA targets. We observed that, unlike genomic DNA, RNA does not remain on the FTA Card during processing, as judged by the time-dependent decrease in signal from the punches during washing and by the weak (or no) RT-PCR signal obtained from the punches compared to the wash solution. Virtually all of the RNA elutes into the initial wash, and this eluted cellular RNA can be directly placed into the first strand reverse transcription reaction or can be ethanol precipitated from the wash solution and resuspended in sterile water or TE before analysis. The results in Figures 3 and 4 demonstrate successful RT-PCR of different mRNA targets from mammalian cells and plant samples, respectively. For the mammalian cell samples, the RT-PCR targets were 626-bp, $1.08-\mathrm{kb}$, and $5.76-\mathrm{kb}$ sequences from $\beta$-actin (Figure 3, panel A), replication protein A (RPA) (Figure 3, panel B), and clathrin-like protein (Figure 3, panel C) mRNAs, respectively. For the potato leaf plant samples, our RT-PCR target consisted of an 852-bp sequence from the 1756-bp cysteine protease mRNA. Negative controls consisted of reactions where reverse transcriptase was omitted during the initial cDNA synthesis step and positive controls consisted of the addition of $100 \mathrm{ng}$ HeLa or $50 \mathrm{ng}$ plant leaf RNA directly to the initial cDNA synthesis step. It is important to include the negative control because we have observed that trace amounts of genomic DNA also elute from the punch during processing, and it is necessary to ascertain that RT-PCR signals are indeed mRNAderived and not from contaminating genomic DNA. The results in Figures 3 and 4 demonstrate that the desired RNA-specific RT-PCR products were obtained with the FTA Card samples stored at $-20^{\circ} \mathrm{C}$ and $-70^{\circ} \mathrm{C}$ and were comparable to the positive controls. We next examined the proportionality of RTPCR signal obtained versus the number of HeLa cells that were spotted onto the FTA Card. Such an experiment would reveal the feasibility of using this method to semiquantitatively measure differential gene expression in biological samples. HeLa cell suspensions at various densities were prepared, and $5-\mu \mathrm{L}$ aliquots of the various suspensions were identically spotted onto FTA Cards (Figure 5). We observed a relationship between the relative amount of RT-PCR product obtained versus the number of cells spotted onto the FTA Cards. These data indicate that, at least semiquantitatively, differences in mRNA levels can be measured by RT-PCR using FTA Cards.

\section{DISCUSSION}

Our analysis indicates that FTA Cards can be used to collect and store biological samples for subsequent RNA analysis by RT-PCR and northern blotting. The quality and integrity of the poly $(\mathrm{A})^{+}$RNA in these samples was preserved, and we were able to obtain RT-PCR product of various sizes as high as $5.76 \mathrm{~kb}$. In northern analysis, the integrity of the hybridization signals was comparable to RNA controls that were isolated directly from biological samples using traditional approaches.

Although RNA and DNA analysis are possible, it is im portant to note that there are differences between the stability and behavior of these nucleic acid types on FTA Cards. In terms of RNA stability, we have found that mammalian cell samples are stable at room temperature and $4{ }^{\circ} \mathrm{C}$ storage for periods up to three and five months, respectively, in the desiccated pouches following sample application. Samples stored at temperatures less than or equal to $-20^{\circ} \mathrm{C}$ are stable for periods of at least one year. It is noteworthy that co-application of protein RNase inhibitors with the mammalian cell samples did not prolong sample stability at the elevated temperatures (data not shown). For plant leaf samples, we found greater restrictions on storage temperature conditions for RNA stability. Potato leaf samples were stable at room temperature, $4^{\circ} \mathrm{C}$, and $-20^{\circ} \mathrm{C}$ for up to five days before decreases in RT-PCR signal were observed. Only storage of the plant leaf samples at $-70^{\circ} \mathrm{C}$ following sample application resulted in the highestquality RT-PCR signal compared to positive controls. Even though there are limitations to sample storage at elevated temperatures, the use of FTA Cards would allow researchers to collect and apply biological samples in environments where freezers are not available. The applied samples can be 
later transferred (albeit shortly thereafter) and secured at the proper lower storage temperatures. This is an advantage over traditional sample collection, which usually requires immediate exposure to liquid nitrogen and storage at temperature less than or equal to $-70^{\circ} \mathrm{C}$ for retrieval of high-quality RNA. Another difference with RNA is that, upon addition of the wash solution to FTA punches, a large percentage of the RNA readily elutes from the punch. Therefore, instead of placing the washed FTA Card punch into the reverse transcription reaction, we recommend addition of an aliquot of the wash solution, which contains the RNA eluate directly to the reverse transcripton reaction. However, the volume of the aliquot must not exceed $10 \%$ of the final volume of the reverse transcription reaction. Addition of aliquots that contribute to greater than $10 \%$ of the reverse transcription reaction volume results in reduction in the amount of RT-PCR product ob- tained, which is potentially due to interference from chemicals and preservatives that elute from the paper with the RNA. Alternatively, the RNA can be ethanol precipitated from the wash solution in the presence of a glycogen carrier because very low amounts of analyte are present. This may be necessary when performing RT-PCR analysis of low copy mRNAs, where large portions of the RNA eluate exceeding $10 \%$ of the final reverse transcription reaction volume must be added to the reverse transcription reaction.

We conclude that the use of FTA Cards for retrieval and analysis of RNA from biological samples is feasible as long as different methods are used for long-term sample storage and processing. The method used to process these samples is rather simple and less complex than RNA preparation methods involving cartridge- or organic-based purification methods. Therefore, it may constitute a method not only for con-
A.

\section{$\begin{array}{lllllllllll}M & 1 & 2 & 3 & 4 & 5 & 6 & 7 & \text { M } & 8\end{array}$}

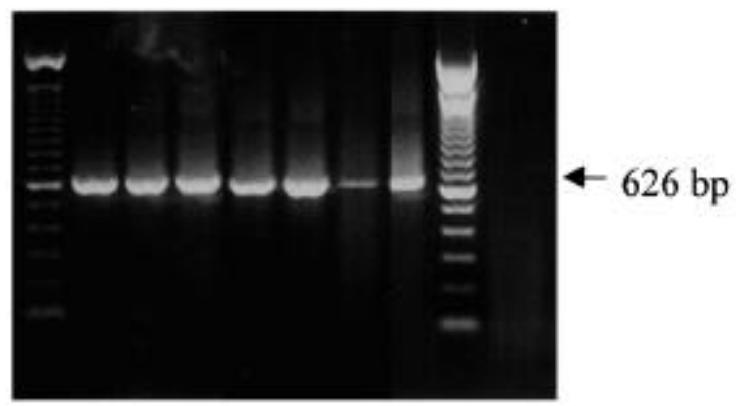

B.
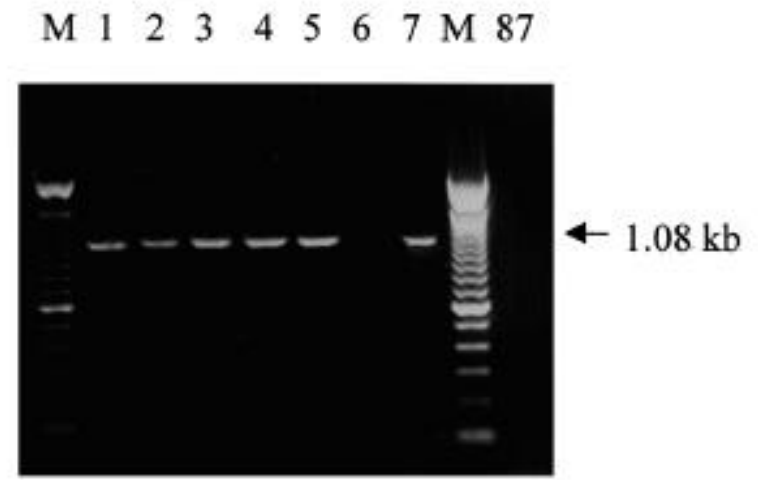

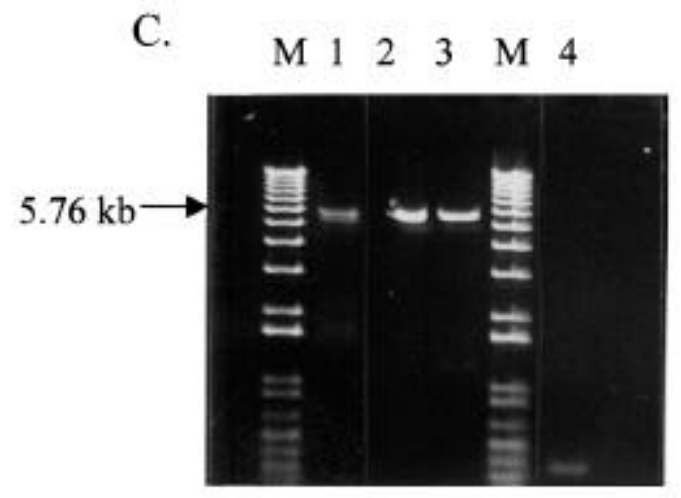

Figure 3. RT-PCR from mammalian cell samples. Eluted RNA was precipitated from washes taken from 2-mm punches of $\mathrm{HeLa}$ cell samples stored at $-20^{\circ} \mathrm{C}$ and $-70^{\circ} \mathrm{C}$ for one year as described in Materials and Methods. The amplification targets were as follows: (A) a 626-bp sequence from $\beta$-actin mRNA (thermal cycling conditions were $94^{\circ} \mathrm{C}$ for $1 \mathrm{~min}$, followed by 40 cycles of $94^{\circ} \mathrm{C}$ for $30 \mathrm{~s}, 60^{\circ} \mathrm{C}$ for $30 \mathrm{~s}$, and $72^{\circ} \mathrm{C}$ for $1.5 \mathrm{~min}$ ); forward and reverse primer sequences were $5^{\prime}$ CCTCGCCTTTGCCGATCC-3' and 5'-GGATCTTCATGAGGTAGTCAGTC- $3^{\prime}$, respectively (7); (B) a 1.08-kb sequence of RPA mRNA (thermal cycling conditions were $94^{\circ} \mathrm{C}$ for $1 \mathrm{~min}$, followed by 40 cycles of $94^{\circ} \mathrm{C}$ for $30 \mathrm{~s}, 55^{\circ} \mathrm{C}$ for $30 \mathrm{~s}$, and $72^{\circ} \mathrm{C}$ for $1.5 \mathrm{~min}$ ); forward and reverse primer sequences were $5^{\prime}$-CAAGATGTGGAACAGTGGATTC-3' and 5'-CATCTATCTTGATGTTGTAACAAGC-3', respectively; and (C) a 5.76-kb sequence of a clathrin-like protein (D21260) mRNA (thermal cycling conditions were $94^{\circ} \mathrm{C}$ for $1 \mathrm{~min}$, followed by 35 cycles of $94^{\circ} \mathrm{C}$ for $20 \mathrm{~s}, 60^{\circ} \mathrm{C}$ for $30 \mathrm{~s}$, and $68^{\circ} \mathrm{C}$ for 7 min); forward and reverse primer sequences were 5'-CCCAGTGACAGGAGGAGACCATA-3' and 5'-ATCCTGTGCTTTTTCTGTGGGAC-3', respectively. For panels A and B, lanes 1-3 and 4-6 are from samples stored at $-20^{\circ} \mathrm{C}$ and $-70^{\circ} \mathrm{C}$, respectively, subsequent to sample application onto FTA Cards, whereas lane 7 is a positive control in which $100 \mathrm{ng}$ HeLa RNA was added to the reverse transcription reaction and lane 8 is a negative control where SUPER SCRIPT II reverse transcriptase was omitted from the reverse transcription reaction. $\mathrm{M}$ is the 100-bp DNA ladder. For panel C, lane 1 is the positive control, HeLa RNA. Lanes 2 and 3 are from samples stored at $-70^{\circ} \mathrm{C}$ subsequent to sample application onto FTA Cards, and lane 4 is the negative control. M is the 1 KB PLus DNA LAdDER TM (Life Technologies). 


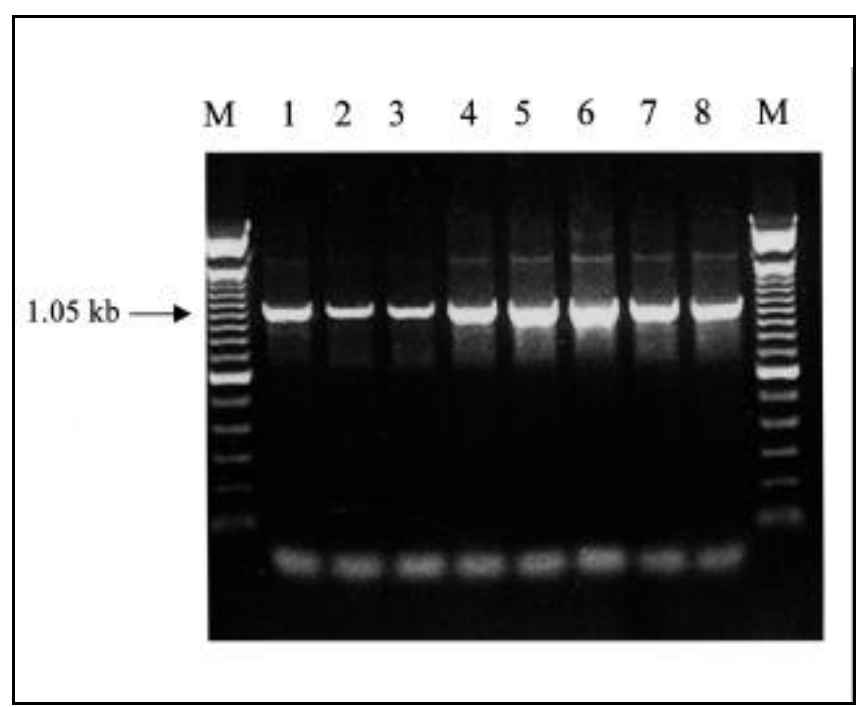

Figure 4. RT-PCR from plant leaf samples. RNA was eluted from 2-mm punches of the leaves from potato plants grown in soil as described in Materials and Methods and stored at $-70^{\circ} \mathrm{C}$ for two weeks. RNA eluate $(5 \mu \mathrm{L})$ was added to each $50-\mu \mathrm{L}$ reverse transcription reaction. Amplification target was a 1.05$\mathrm{kb}$ sequence from a 1.8-kb cysteine protease (AJ003137) mRNA using the following forward and reverse primer sequences, respectively, $5^{\prime}$-TCGCCGATCTGACTAATGAGGAG-3' and 5'-ATGCGCTTCATTGCCTTCACTCC- ${ }^{\prime}$. Thermal cycling conditions were $94^{\circ} \mathrm{C}$ for $1 \mathrm{~min}$, followed by 40 cycles of $94^{\circ} \mathrm{C}$ for $30 \mathrm{~s}, 60^{\circ} \mathrm{C}$ for $30 \mathrm{~s}$, and $72^{\circ} \mathrm{C}$ for $2 \mathrm{~min}$. $\mathrm{M}$ is the 100-bp DNA ladder. Lanes 1-3 and 4-7 are from samples stored at $-20^{\circ} \mathrm{C}$ and $-70^{\circ} \mathrm{C}$, respectively, subsequent to application on FTA Cards, whereas lane 8 is a positive control in which $50 \mathrm{ng}$ potato leaf RNA was added to the reverse transcription reaction.

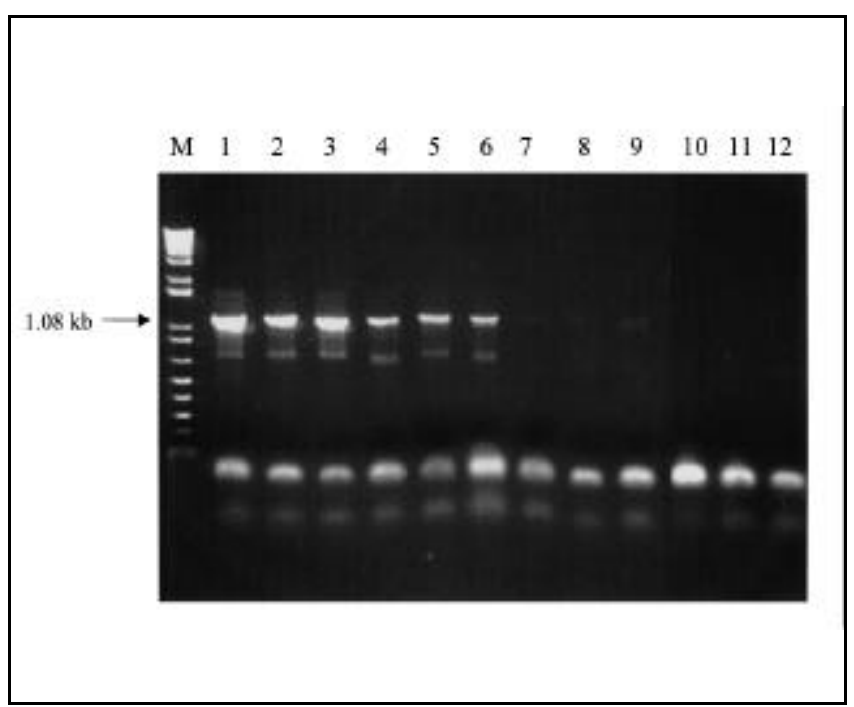

Figure 5. Dependence of RT-PCR signal on the amount of biological sample stored on FTA Cards. Samples $(5 \mu \mathrm{L})$ of suspensions of HeLa cells at different cell densities were spotted onto FTA Cards, allowed to air dry for $1-2 \mathrm{~h}$, and then stored at $-70^{\circ} \mathrm{C}$ for over one year. The 2-mm punches were taken from the samples and treated as described in Materials and Methods. An aliquot of the RNA (1/80th of the total volume of the wash) was used for RT-PCR as described in Materials and Methods. The target was an approximately $1.08-\mathrm{kb}$ product of the RPA gene, and PCR primers and conditions are described in the legend to Figure 3. M is the 1 KB PLus DNA LADDER. Lanes $1-3,25000$ cells; lanes $4-6,5000$ cells; lanes 7-9, 500 cells; lanes $10-12$, negative controls where SUPERSCRIPT II RNase H- reverse transcriptase was omitted from the reverse transcription reaction. venient collection and storage of biological samples but also for rapid RNA preparation and RT-PCR analysis of both plant and mammalian tissue and cell samples.

Note added in proof: mRNA from samples (BHK-21) stored on FTA has been used successfully in construction of cDNA libraries.

\section{ACKNOWLEDGMENTS}

The authors wish to thank Ms. Kala Sitarman and Dr. Jun E. Lee for plant primer sequences, Mr. Ryan Fleming for technical assistance in obtaining plant samples, Ms. Kim Butash for growing BHK-21 cells, and Dr. J.J. Lin for helpful discussions.
7.Raff, T., M. van der Giet, D. Endemann, T. Wiederholt and M. Paul. 1997. Design and testing of $\beta$-actin primers for RT-PCR that do not coamplify processed pseudogenes. BioTechniques 23:456-460.

8.Rogers, C. and L. Burgoyne. 1997. Bacterial typing: storing and processing of stabilized reference bacteria for polymerase chain reaction without preparing DNA an example of an automatable procedure. Anal. Biochem. 247:223-237.

9.Sambrook, J., E.F. Fritsch and T. Maniatis. 1989. Molecular Cloning: A Laboratory Manual, 2nd ed. CSH Laboratory Press, Cold Spring Harbor, NY.

10.Sitaraman, K., M. Darfler and B. Westfall. 1999. Amplification of large DNA from blood stored at room temperature. Focus 21:10.

Address correspondence to Donna K. Fox, Life Technologies, 9800 Medical Center Drive, Rockville, MD 20850, USA. e-mail:dfox@lifetech.com

\section{REFERENCES}

1.Belgrader, P., S.A. Del Rio, K.A. Turner, M.A. Marino, K.R. Weaver and P.E. Williams. 1995. Automated DNA purification and amplification from blood-stained cards using a robotic workstation. BioTechniques 19:426-432.

2.Burgoyne, L., J. Kijas, P. Hallsworth and J. Turner. 1994. Proc. Fifth Int. Symp. Human Ident.

3.Burgoyne, L.A., D.J. Carroll, C. Rogers and J. Turner. 1997. Conventional DNA Collection and Processing: Disposable Toothbrushes and FT ${ }^{\circledR}$ Paper as a Non-Threatening Buccal-Cell Collection Kit Compatible with Automatable DNA. Proc. 8th Int. Symp. Hum. Ident.

4.Ciccarone, V., Y. Chu, K. Schifferli, J.-P. Pichet, P. Hawley-Nelson, K. Evans, L. Roy and S. Bennett. 1999. LIPOFECTAMINETM 2000 reagent for rapid, efficient transfection of eukaryotic cells. Focus 21:54-55.

5.Del Rio, S.A., M.A. Marino and P. Belgrader. 1996. Reusing the same blood-stained punch for sequential DNA amplifications and typing. BioTechniques 20:970-974

6.Hansen, P. and R. Blakesley. 1998. Simple archiving of bacterial and plasmid DNAs for future use. Focus 20:72-74. 